\title{
Adoption of Plant Protection Strategies by Farmers of Virudhunagar District of Tamil Nadu, India
}

\author{
V. Jothika* and R. Rajasekaran \\ Agricultural Extension, Department of Social Sciences, Agricultural College and Research \\ Institute, Killikulam -628252, India \\ *Corresponding author
}

\begin{tabular}{l} 
Ke y w o r d s \\
$\begin{array}{l}\text { Plant Protection, } \\
\text { Adoption, Chemical } \\
\text { methods, Bio } \\
\text { control methods }\end{array}$ \\
\hline Article Info \\
$\begin{array}{l}\text { Accepted: } \\
\text { 15 April } 2020 \\
\text { Available Online: } \\
\text { 10 May } 2020\end{array}$ \\
\hline
\end{tabular}

\section{A B S T R A C T}

Pest and disease problems on agricultural crops were known since the domestication of wild plants. Indiscriminate use of agrochemicals for the past few decades led to produce detrimental effect at all walks of life by polluting/degrading the soil, water and environment. Plant protection is practice of managing plant diseases, weeds and pests that damage agricultural crops and forestry. The present study was carried out in the Virudhunagar district of Tamil Nadu. Ex Post facto design was used and sample size of 30 was selected randomly. The following data such as the profile of the farmers, the awareness of the hazards of chemical control and the awareness of benefits of the bio control measures, the plant protection methods usage behaviour of farmers were collected by personal interview with the help of a well-structured and pre-tested interview schedule and analysed using percentage and cumulative frequency. The results were tabulated and the reasons for the non adoption of bio control measures were obtained. This paper also deals with the suggestions to improve the adoption of bio control measures.

\section{Introduction}

Plant protection is the science and practice of managing plant diseases, weeds and pests that damage agricultural crops and forestry.Pest and disease problems on agricultural crops were known since the domestication of wild plants. High yielding varieties, monoculture and use of heavy dose fertilizers have invited this harshness of pests and diseases in more intensive form. The chemical pesticides came into application since 1940. Indiscriminate use of agrochemicals to the crops had led to produce detrimental effect at all walks of life by polluting or degrading the soil, water and environment. They intoxicate the food chain as well as the food web. Plant protection measures are carried out to minimize the yield reduction in crops as well to safeguard them during the production time and afterwards (Ezhil Vendan, 2016). There are various forms of plant protection which includes 
physical methods, chemical methods, biotechnical methods, biological methods and integrated methods.

Pesticide use has certainly contributed towards improving agricultural production in terms of both yield and quality thus increasing agricultural income particularly in developed countries. However careless use of pesticides without adhering to the safety norms and recommended practices has posed serious health risks to humans, other living organisms, and the environment, from onfarm workers' exposure and release of chemicals into the air and water, to commodities containing pesticide residues (Damalas, 2009). Public awareness about the adverse effects of pesticides on the safety of foods and on the environment has increased in recent years and the search for alternatives to widely used chemical pesticides including bio pesticides has become a priority (Pelaez and Mizukawa, 2017). This study was carried out of interest to know what kind of plant protection methods were followed by the farmers the reasons for their adoption and non adoption of different measures.

The main objectives of this study include to measure the extent of adoption of chemical control and biological control of plant protection. Next to study the awareness and opinion about the hazards of chemical control measures. Also to study the awareness and opinion about the benefits of biological control measures. Finally to find out the plant protection methods usage behaviour of farmers.

\section{Materials and Methods}

Ex-post facto research design was used in this study which will suit the objectives and type of information needed.The study was taken in the Virudhunagar district of Tamil Nadu and the respondents were selected randomly from the two blocks namely Tiruchuli and Arupukottai. In each block two villages were selected randomly viz., Muthuramalingapuram, Kathalampatti, Kovilangulam and Gopalapuram. About 15 farmers per block were selected randomly from each village. Hence a total number of 30 farmers were selected randomly for the study. The data were collected by personal interview with the help of a well-structured and pretested interview schedule and analyzed using percentage analysis and cumulative frequency.

\section{Results and Discussion}

The profile of the farmers were studied and summarized. The data regarding the profile of the respondents were analyzed using percentage analysis and the results are presented in the Table 1.

From Table 1, it could be inferred that majority of the respondents $(66.67 \%)$ were under the old age group followed by middle age group $(30.00 \%)$. Nearly three fourth of the respondents $(73.33 \%)$ were male. The higher education qualification was obtained at the Secondary level $(43.33 \%)$ and most of the respondents had farming experience of more than 25 years $(63.33 \%)$. More than half of the respondents had Social Participation (53.33 $\%)$. About 56.67 per cent of the respondents had contact with the extension agents.

From the Table 2, it could be revealed that $43.33 \%$ of the respondents had large farm size followed by medium farm size (33.33 5). More than three fourth of the respondents had more than one type of land $(36.66 \%)$ which included garden land and wet land followed by garden land $(30.00 \%)$. Most of the respondents $(63.33 \%)$ practiced more than two crops per season and the major crop that was grown was cotton $(63.33 \%)$ since the black soil was predominant in the study area 
followed by maize crop $(33.33 \%)$ as garden land was possessed by many farmers.

Table 3 depicts that more than half of the respondents $(56.67 \%)$ were practicing chemical method of plant protection followed by combination of both chemical and biological method of plant protection (30.00 $\%)$. They did not adopt the bio control measure as they felt that they could not meet out the expenses in case for yield reduction during initial years of adoption .Only 13.33 per cent of the respondents practiced biological methods and this was attained through the trainings and tours. Cent per cent of the respondents were aware of the hazards of the chemical method of plant protection as well as the benefits of biological control measures.

From Table 4, it could be concluded that the idea of adopting the bio control measures was obtained from the extension agents which was about 61.53 per cent followed by tours $(23.37$ $\%)$. About $61.53 \%$ of the respondents adopted the bio control method up to five years followed by 30.77 per cent who had adopted for more than five years. The source of information regarding the bio control measures was the extension agents $(69.27 \%)$ followed by their own interest $(15.38 \%)$. About 69.27 per cent of the respondents adopted the bio control measures for the purpose of high yield followed by pest control $(61.53 \%)$. The respondents who adopted the bio control measures prepared the bio control products on their own (53.84 \%) which predominantly included Neem and other home wastes followed by procurement from the shops which included the composts and the bio control agents. Similar finding was identified by Shafiqul Islam and Akil Morshes (2013).

Table.1 Profile characteristics of farmers $(n=30)$

\begin{tabular}{|l|l|c|c|}
\hline \multirow{2}{*}{ Characteristics } & Category & \multicolumn{2}{|c|}{ Respondents } \\
\cline { 3 - 4 } & & Number & Percentage \\
\hline Age & Young & 1 & 3.33 \\
& Middle & 9 & 30.00 \\
& Old & 20 & 66.67 \\
\hline \multirow{2}{*}{ Gender } & Male & 22 & 73.33 \\
\hline Education Qualification & Female & 8 & 26.67 \\
\hline \multirow{2}{*}{ Farming Experience } & Illiterate & 2 & 6.67 \\
& Primary & 4 & 13.33 \\
\hline Member of any Farmer's & Secondary & 13 & 43.33 \\
group & Higher Secondary & 2 & 6.67 \\
\hline Contact with extension & Graduate & 9 & 30.00 \\
\hline agents & Less than 25 years & 11 & 30.67 \\
& More than 25 years & 19 & 63.33 \\
\hline & Member & 14 & 46.67 \\
& Not a member & 16 & 53.33 \\
\hline & In contact & 13 & 43.33 \\
\hline & Not in contact & 17 & 56.67 \\
\hline
\end{tabular}


Table.2 Land holding status of the farmers $(n=30)$

\begin{tabular}{|l|l|c|c|}
\hline Characteristics & Category & \multicolumn{2}{|c|}{ Respondents } \\
\cline { 2 - 4 } Size of farm & Small & 7 & 23.33 \\
& Medium & 10 & 33.33 \\
& Large & 13 & 43.34 \\
\hline \multirow{2}{*}{ Type of land } & Wet land & & \\
\cline { 2 - 4 } & Garden land & 2 & 6.66 \\
\cline { 2 - 4 } & Dry land & 9 & 30.00 \\
\cline { 2 - 4 } & More than one type & 11 & 26.67 \\
\hline \multirow{2}{*}{ Crops grown } & Growing only one crop & & 36.67 \\
\hline & Growing more than one crop & 11 & 36.67 \\
\hline
\end{tabular}

Table.3 Method and awareness of plant protection $(n=30)$

\begin{tabular}{|c|c|c|c|}
\hline \multirow[t]{2}{*}{ Characteristics } & \multirow[t]{2}{*}{ Category } & \multicolumn{2}{|c|}{ Respondents } \\
\hline & & Number & Per cent \\
\hline $\begin{array}{l}\text { Method of plant } \\
\text { protection }\end{array}$ & $\begin{array}{l}\text { Chemical } \\
\text { Biological } \\
\text { Both }\end{array}$ & $\begin{array}{c}17 \\
4 \\
9\end{array}$ & $\begin{array}{l}56.67 \\
13.33 \\
30.00\end{array}$ \\
\hline $\begin{array}{l}\text { Awareness about the } \\
\text { hazards of chemical } \\
\text { control measures }\end{array}$ & $\begin{array}{l}\text { Aware } \\
\text { Not Aware }\end{array}$ & $\begin{array}{c}30 \\
0\end{array}$ & $\begin{array}{c}100.00 \\
0.00\end{array}$ \\
\hline $\begin{array}{l}\text { Awareness about the } \\
\text { benefits of biological } \\
\text { control measures }\end{array}$ & $\begin{array}{l}\text { Aware } \\
\text { Not Aware }\end{array}$ & $\begin{array}{c}30 \\
0\end{array}$ & $\begin{array}{c}100.00 \\
0.00\end{array}$ \\
\hline
\end{tabular}


Table.4 Biological control methods $(n=13)$

\begin{tabular}{|c|c|c|c|}
\hline \multirow[t]{2}{*}{ Characteristics } & \multirow[t]{2}{*}{ Category } & \multicolumn{2}{|c|}{ Respondents } \\
\hline & & Number* & Per cent \\
\hline $\begin{array}{l}\text { Idea of adopting bio control } \\
\text { method }\end{array}$ & $\begin{array}{l}\text { Own } \\
\text { Extension Agent } \\
\text { Information Technology } \\
\text { Tours }\end{array}$ & $\begin{array}{l}2 \\
8 \\
0 \\
3\end{array}$ & $\begin{array}{c}15.38 \\
61.53 \\
0.00 \\
23.07\end{array}$ \\
\hline $\begin{array}{l}\text { Years of adoption of bio } \\
\text { control method }\end{array}$ & $\begin{array}{l}\text { Less than } 1 \text { year } \\
1-5 \text { years } \\
\text { More than } 5 \text { years }\end{array}$ & $\begin{array}{l}1 \\
8 \\
4\end{array}$ & $\begin{array}{l}7.70 \\
61.53 \\
30.77\end{array}$ \\
\hline $\begin{array}{l}\text { Source of information of } \\
\text { bio control method }\end{array}$ & $\begin{array}{l}\text { Own } \\
\text { Other farmers } \\
\text { Extension Agent } \\
\text { Information Technology }\end{array}$ & $\begin{array}{l}2 \\
1 \\
9 \\
1\end{array}$ & $\begin{array}{c}15.38 \\
7.70 \\
69.27 \\
7.70\end{array}$ \\
\hline $\begin{array}{l}\text { Purpose of usage of bio } \\
\text { control methods }\end{array}$ & $\begin{array}{l}\text { Pest control } \\
\text { High yield } \\
\text { Encompassing culture } \\
\text { Need based use of chemical } \\
\text { pesticide } \\
\text { Make eco friendly product }\end{array}$ & $\begin{array}{l}8 \\
9 \\
3 \\
0 \\
5\end{array}$ & $\begin{array}{c}61.53 \\
69.27 \\
23.07 \\
0.00 \\
\\
38.46\end{array}$ \\
\hline Preparation of bio inputs & $\begin{array}{l}\text { Prepared on own } \\
\text { Procured from outside } \\
\text { Both }\end{array}$ & $\begin{array}{l}7 \\
2 \\
4\end{array}$ & $\begin{array}{l}53.84 \\
15.38 \\
30.76\end{array}$ \\
\hline $\begin{array}{l}\text { Discussion with } \\
\text { otherfarmers }\end{array}$ & $\begin{array}{l}\text { Discuss with others } \\
\text { Do not discuss with others }\end{array}$ & $\begin{array}{c}12 \\
1\end{array}$ & $\begin{array}{c}92.30 \\
7.70\end{array}$ \\
\hline $\begin{array}{l}\text { Awareness from the } \\
\text { department side }\end{array}$ & $\begin{array}{l}\text { Awareness given } \\
\text { Awareness not given }\end{array}$ & $\begin{array}{c}10 \\
3\end{array}$ & $\begin{array}{l}76.92 \\
23.08\end{array}$ \\
\hline $\begin{array}{l}\text { Level of satisfaction in the } \\
\text { adoption of bio control } \\
\text { method }\end{array}$ & $\begin{array}{l}\text { Very less satisfied } \\
\text { Satisfied } \\
\text { Very much satisfied }\end{array}$ & $\begin{array}{l}1 \\
5 \\
7\end{array}$ & $\begin{array}{c}7.70 \\
38.46 \\
53.84\end{array}$ \\
\hline
\end{tabular}

*-multiple responses obtained

The farmers who practiced bio control method of plant protection discuss with other farmers about the measures they practiced and the measures they wanted to $(92.30 \%)$. More than three fourth of the respondents $(76.92 \%)$ got awareness from the department side regarding the use of bio control measures which they procure from outside. The satisfaction level of the farmers in adoption of bio control measures were obtained as high by nearly fifty per cent $(53.84 \%)$. This was due to the increase in the yield and the improvement of the soil health.

In conclusion, plant protection is not only for the plants it is also for the protection of environment which includes the soil, groundwater, air and the food chain. Hence the farmers should take the responsibility for the protection of the plants using bio control 
agents. From the above study it could be concluded that the farmers were aware of hazards of the chemical methods as well as the benefits of the bio control methods of plant protection. But the adoption of bio control measures was minimum and it was practiced by the farmers possessing larger farm size and the small farmers were not ready to adopt due to the reasons such as availability and preparation of bio pesticide, financial crisis, yield reduction, vanishing of livestock maintenance habit by the farming community. Therefore the adoption can be improved by conducting more awareness programme from the department, Government can make policies such as providing finance to the initial adopters of bio control measures to meet out the yield reduction, take measures to provide knowledge regarding the preparation and use of bio control agents and the eextension workers can guide and support the farmers regarding the adoption of bio control measures.

\section{References}

Damalas C.A. Understanding benefits and risks of pesticide use, 2009, 4:945949.

Ezhil Vendan. Current scenario of biopesticides and ecofriendly insect pest management in India, 2016, 2:268-271.

Pelaez V and Mizukawa G. Diversification strategies in the pesticides industry: From seeds to biopesticides, 2017, 2:267-273.

Shafiqul Islam and Akil Morshes. Study on homemade biopesticide and organic pest management in organic farming, 2013, 7:18-25.

http://wgbis.ces.iisc.ernet.in/

\section{How to cite this article:}

Jothika, V. and Rajasekaran, R. 2020. Adoption of Plant Protection Strategies by Farmers of Virudhunagar District of Tamil Nadu, India. Int.J.Curr.Microbiol.App.Sci. 9(05): 1907-1912. doi: https://doi.org/10.20546/ijcmas.2020.905.217 